\title{
Quo Vadis Legal Protection for Children Recruited as Child Soldiers in Areas of Armed Conflict in the Context of International Law
}

\author{
Herman Suryokumoro $^{\mathrm{a}}$, Ikaningtyas ${ }^{\mathrm{b}}$, M. Muafi ${ }^{\mathrm{c}}$ \\ ${ }^{\text {a}}$ Faculty of Law Brawijaya University, Indonesia \\ Email: hermans-fh@ub.ac.id \\ ${ }^{b}$ Faculty of Law Brawijaya University, Indonesia \\ Email: ninktyas@ub.ac.id \\ ${ }^{c}$ Departement of Sociology, London School of Economics and Political Science, United \\ Kingdom \\ Email: muafimochamad@gmail.com
}

Submitted : 2020-07-23 | Accepted : 2020-09-25

\begin{abstract}
The objective of this research is to analyze legal protection of children who become child soldiers in areas experiencing armed conflict. Various international legal instruments that regulate the prevention, protection, and even enforcement for violators of certain international legal instruments on the recruitment of children as child soldiers have actually not been able to reduce the number of children who become victims in armed conflict, particularly those who are directly involved as child soldiers. This is because normatively, there are still some problems on the uniformity of definition of children age as well as the classic problem of the binding power of all related international legal instruments, being whether or not they create compulsory obligation. Legal protection for children who are recruited as child soldiers must be implemented because in the perspective of human rights, the right of children to live safely and comfortably for their proper growth and development is a fundamental right that must be complied by all states (ius cogens). If a state does not grant protection, and even allows children to be directly involved in armed conflict, then international legal sanctions may be imposed.
\end{abstract}

Keywords: Children protection, child soldiers, armed conflict

\section{INTRODUCTION}

Armed conflict or war is often chosen by states around the world as the last resort to resolve a long-standing dispute or conflict between one state and another, or an internal conflict within that state. For world leaders, armed conflict may become a tool in an ideological battle, but for civilians and children, an armed conflict is considered analogous to a horrible, extended, and neverending nightmare. War often leaves behind traumatic scars and psychological suffering that are far more torturous than physical injury or a disability. Armed conflict often occurs in a cruel manner and has no regard for humanitarian aspects. 
There are several parties that may become subjects to an armed conflict, among which are combatants. Combatants are the parties that are actively involved and participate in conflict, who as such become the target of attacks and may kill and be killed, but if captured will be treated as prisoners of war. ${ }^{1}$ Among residents or civilians in a region where armed conflict occurs, there are groups of children who often become victims in that conflict. Children often experience the adverse effects of war or armed conflict. Children are extremely vulnerable and their development much depends on their surrounding environment. Armed conflict may have negative impacts on the development of children; in contrast, children should be able and allowed to develop properly, accompanied by love, affection, activeness, and major expectations for their future.

However, in armed conflict children suffer different ways than an adult, it is because that child has physically weaker and their mentality not in the same level as adult. Consequently, their physical, mental and psychosocial development will suffer from the armed conflict condition. ${ }^{2}$

A different reality occurs for children who live in areas of armed conflict. Their childhoods are spent in harsh and grave conditions that, in contrast, should not be experienced by them. These conditions are triggered by the struggle and violence that occur in the situation. Often, children become victims of social discrimination, aggression, evacuation, violence, and exploitation from activities in war.

UNICEF had documented 170,000 cases of severe violations toward underage children since 2010, including murder, inflicting disability, kidnapping, sexual harassment, and recruitment into armed groups $^{3}$. A report by UN Secretary-General António Guterres that was published on Friday, June 28, 2019 stated that the number of deaths and injured victims includes the part of 11,779 severe violations committed toward children in Yemen, which occurred from April 1, 2013 to December 31, 2018. Other violations involve the recruitment of children as combatants and their arrest because of suspected or full involvement with the parties who are tied to the conflict. ${ }^{4}$ In several states such as Uganda, Myanmar, Ethiopia, and Guatemala, children are conscripted or enlisted by the state ${ }^{5}$.

The annual report that has been published by the UN special agency for children has revealed brutalities toward children, in which children are misused as soldiers in war or armed conflict between states. About $40 \%$ of the child soldiers in the world is estimated in Africa continent, however the child soldier still become global phenomenon. ${ }^{6}$ In states such as Liberia, a

1 Nils, Melzer, International Humanitarian Law: A Comprehensive Introduction, (Geneva: ICRC 2019) p.81-85

2 George Graham, Mariam Kirollos, (Report writer), Stop The War on Children, (Germany: VierCprint+mediafabrik, 2019) p.22

3 Benekdita, Miranti, UNICEF: 2010-2019 Jadi Dekade Mematikan Bagi Anak Daerah Konflik [UNICEF: 2010-2019 Becomes the Most Deadly Decade for Children in Areas of Conflict], https://www.liputan6.com/global/read/4145033/u nicef-2010-2019-jadi-dekade-mematikan-bagianak-daerah-konflik, accessed on April 10, 2020.

4 BBC News Indonesia, Serangan terhadap anak di wilayah perang sangat mengejutkan [Attacks on children in war areas are very surprising], https://www.bbc.com/indonesia/majalah42501881, accessed on April 10, 2020.

5 Muhammad Joni, Aspek Hukum Perlindungan Anak Dalam Perspektif Konvensi Hak Anak [Aspects of Child Protection Law in the Perspective of the Convention on the Rights of the Child], (P.T Citra Aditya Bakti, Bandung, 1999), p. 1.

6 Mark A. Drumbl, The Effects of The Lubanga Case on Understanding and Preventing Child 
quarter of the children are involved in armed conflict between factions. Armed conflict has claimed many child victims in states such as Mozambique, Angola, Afghanistan, Somalia, Sudan, Cambodia, Haiti, and Bosnia ${ }^{7}$.

More than 300,000 boys and girls under the age of 18 were recruited and perused as government soldiers or rebel soldiers in armed conflict in more than 30 states around the world ${ }^{8}$. In large numbers, the children are often recruited in order to have them take part as government soldiers, paramilitary, and infantries, and in various kinds of activities that are usually conducted by armed groups. Millions of children around the world have even received and been introduced to matters of military and war since they have been in elementary schools or educational institutions that are equivalent to elementary schools. Further, what becomes the most surprising is that in addition to children from the ages of 15 to 18 years, the youngest children who have become victims of such recruitment are children who are only seven years in age 9 .

The usage of children in groups of armed militia is considered to be very advantageous by the parties in an armed conflict. The most perceived advantage is that underage children are considered not to possess logic and act recklessly without prior thinking, and as soldiers are often placed on the front line as shields and they never think about welfare (salary and benefits) - what is important is that they still receive their dietary needs ${ }^{10}$. Many underage children become soldiers in the front line of an armed

Soldering, Yearbook of International Humanitarian Law, Vol. 1, 2012, p.92.

7 Ibid, p. 2.

8 Mungoven, Rory. Global Report on Child Soldiers Part 1. Child Soldiers Global Report, 2018, p.10.

9 Ibid., p. 10. conflict. When many of them become soldiers on the battlefield, other children are recruited to be made and utilized as spies, messengers, guards, minesweepers, (unskilled) laborers, attendants, prostitutes, and workers in other activities that go against the will of their families or surrounding environment.

The usage of children in warfare according to the International Criminal Court is a form of war crime. This is based on the understanding that children constitute civilians and should not be involved in activities in armed conflict. UNICEF also stated that "state and non-state entities must commit themselves to stop the recruitment and use of child as soldier or adjuncts to armed group" 11 . International humanitarian law also emphasize the protection of human rights for civilians, particularly for underage children. The issue of child protection itself has been brought up as an important discussion since the end of World War I; child protection was raised after the development of the issue regarding equal rights for women. A number of related conventions and regulations have been codified, such as the Geneva Convention of 1940, Additional Protocol I of 1977, and Convention on the Rights of the Child of 1989 that has been ratified by 185 states in the world.

There are several conventions and/or resolutions that regulate children in international law, among which is the Convention on the Rights of the Child, and protocols that regulate the rights and obligations of children when war occurs, as

10 Reinhard Hutagaol, Tentara Anak (Child Soldiers). http://reinhardjambi.wordpress.com. Accessed on March 18, 2020.

11 UNHCR, Protectiong Children during Armed Conflict, Unichef, 2006 
the Optional Protocol to the Convention on the Rights of Child on the Involvement of Children in Armed Conflict. In addition, children are one of the subjects that are required to be protected in times of armed conflict, and they are also awarded special protections regulated in the Fourth Geneva Convention of 1949 as well as Additional Protocol I and Additional Protocol II of 1977. ${ }^{12}$ These international conventions are fundamental for the protection of children who are directly involved in armed conflict.

In Indonesia, there are national regulations that regulate the protection of children who become victims in armed conflict, such as Law No. 59 of Year 1958 on the Ratification of the 1949 Geneva Conventions, Law No. 4 of Year 1979 on Child Welfare, Presidential Decree No. 36 of Year 1990 on the Ratification of the Convention on the Rights of the Child, and Law No. 35 of Year 2014 on the Amendment to Law No. 23 of Year 2002 on Child Protection. These regulations and laws are guidelines for the state of Indonesia in establishing legal protection of the rights of children and become a reference for the viewpoint of Indonesia according to international regulations that also reject the involvement of children in all activities that are related to armed conflict.

Legal protection for children in situations of armed conflict has the objective to protect children, and it is intended to be able to defend the rights of children as well as their interests. However, in its reality and execution, international laws that regard child protection has not been able and has not been effective in regarding the issue of child soldiers. This has also been the result of the existence of international laws that regard

12 Sulaf Abdullah Hama Rashid, 'International Protection for Victim of Sexual Violance During child protection that need to be tested and developed further and the lack of awareness of the international community (whether individual or party states to the treaties) to be able to get involved and participate voluntarily in upholding the substance of the child protection laws. The legal norms that are found in regulations and conventions for the legal protection of children rights are very limited when applied to the real situation. To date, issues regarding children in the world are still regarded as less important, and thus the issues are often cast aside to international discourses. In addition, the ever-growing ease in circulation of modern weaponry and the ease of use of those weapons contribute to the appearance of child soldiers in areas with armed conflict. As well, the presence of children who are involved in armed conflict in different states around the world is a presence that becomes an undeniable matter.

The issue regarding child soldiers is now becoming more and more prevalent, and often the discourse regarding child soldiers is not taken seriously by international forums. Therefore, this study brings up the issue regarding importance of providing legal protection for children who are recruited as child soldiers, by utilizing the method of normative legal research with the statute approach and case approach. The objective of this study is to analyze whether international instruments regarding legal protection of children has become sufficient to provide protection to children who are recruited as child soldiers.

\section{LEGAL MATERIALS AND METHODS}

This research is a normative-doctrinal research using a statutory approach. 
Approaching legislation is used to review international legal instruments related to legal protection for children recruited as child soldiers in times of armed conflict, namely: the 1949 Geneva Convention and the 1977 additional protocol and the 1989 Convention on the Rights of the Child, Optional Protocol on Involvement of Children in armed Conflict. These legal instruments were analyzed using interpretation techniques to obtain a comprehensive explanation of the legal protection for child soldiers.

\section{RESULT AND DISCUSSION}

Factors That Compel the Recruitment of Children as Child Soldiers in Areas of Armed Conflict

The utilization of children as soldiers or combatants has started from early on, approximately since the $18^{\text {th }}$ century. At that time, children often indirectly participated in activities of armed conflict. At first, the children were only designated as inactive participants or in other words only as the supporters of an armed conflict, but over time, the utility of children in their participation started to shift and diversify, beginning with the activity of recruiting children as cadets or troops who act to aid a war army directly when armed conflict occurs and some of them used by the soldier for "sexual purpose"13.

In current times, underage children are recruited and forced to become rebel groups, separatist fighters, guerilla fighters, fundamentalist groups, "right-wing" actors, and even government-owned armed military. Involvement of underage children in warfare occurs in almost every country currently engaged in war, and this not only occurs just

13 Çocuklar ve savasin and Saglik etkileri, 'Children and Health effects of War: Being A War Child', (2017) 39 (4) Cumhuriyet Medical Journal, p.641 for boys but also for girls. The number of children who are involved in armed conflict has proven that the protection of rights for children in accordance with what has been written in and regulated by the 1949 Geneva Convention and the 1989 Convention on the Rights of the Child has not been executed well.

The participation of children as child soldiers is caused by several causative factors that then become the reason of their participation in certain groups of armed militia. Children who are prone to take part as soldiers are children who usually live in conflict areas and in general originate from urban or rural resident communities, but belong to marginalized community groups or are impoverished people. The participation of children in armed conflict is often as a result of being compelled to do so. The largest number of children who are recruited as child soldiers are teenage boys; over the course of developments, the recruitment has had a greater tendency to involve girls in greater numbers, and their recruitment has increased in recent years. In addition to being recruited as soldiers, girls often experience sexual harassment, and they are forced to marry by soldiers of armed militia that they follow ${ }^{14}$.

There are several reasons why children may become soldiers voluntarily:

1. Objective features of children's pre-war and war-related experiences that may be in the form of:
a. Militarization of Daily Life
b. Physical and Structural Violence Violence supported by the social structure that is present in the environment where someone lives, for example occurrences of injustice
14 Why children join, http://www.child- soldiers.org/childsoldiers/why-children-join, accessed March 20, 2020.


toward certain minority groups. This experience then leads to the desire to replace the order that is considered wrong.

c. The Better of the Bad Alternatives For residents who have experienced loss of wealth, relatives, and residence, the choice to become a soldier may be the best possibility among the worst ones that are present.

Subjective Appraisal: A Child's Evolving Capacity to Evaluate and to Decide $^{15}$

2. Children cannot yet indicate their own desire; what is recognized as voluntary involvement may be considered to be the result of indoctrination conducted by adults to persuade children to participate in and join armed troops. The decision is very much affected by the communities or groups where they reside because children do not yet possess high analytical capabilities for everything present in their environments. Therefore, international law does not permit the utilization of children in various kinds of activities that are related to armed conflict, even if the involvement of the children is on a voluntary basis.

3. The Influence of Children's Ecologies

a. Influence of religion or faith that is adhered to, ideology of certain classes or groups, and indoctrination given by adults.

b. Influence of social or community values that are present where the children live and grow, as well as the learning process and the giving of love and affection by the family. c. Peer pressure, or the principle that every person is thought to be doing the same thing - "everyone is doing it".

4. Development Processes

a. Armed groups do not have much difficulty in recruiting children because they have not reached maturity, and thus they are easily affected and manipulated. Children can be easily brainwashed in order to possess excessive courage and to form their obedience.

b. There is the "desire for revenge" because they incurred the loss of their families. In addition, they have no places for protection and thus obtain these as well as food from armed groups.

c. There is the loss of opportunity to obtain an education. In a very impoverished situation where schools have been destroyed and teachers are limited in number, children will seek for alternatives for a better life.

d. Children possess the viewpoint that they can be proud of becoming a soldier. This is in addition to political propaganda that leads to one-sided truths for which defending them becomes a heroic act (by the feeling of helplessness and feeling of vulnerability).

e. Peer pressure from friends and family foster a high sense of solidarity for their groups, which leads to children unconsciously and voluntarily becoming soldiers.

From the factors mentioned above, the most dominant factor that affects the

15 Roos Haer, 'The Study of Child Soldering: Issues and Consequences for DDR Implementation' (2016) Third World Quartely, p.5 
participation of children in armed forces is direct influence from the environment ${ }^{16}$ where children live and grow, because the situation of the environment where children grow is the place where children obtain a second kind of education after the first kind, the kind they obtain from their families.

Several advantages are very much considered to support the utilization of children as members of armies, which among others are that children are perceived to be cheaper, more easily expendable, more accepting of indoctrination and brainwashing, high in possessed obedience and loyalty, and more inclined to act without much consideration to complete a task (unthinking obedience). In addition, uneven discrepancies in society and the economy such as poverty, alienation, discrimination, and the partiality of the system - particularly legal systems that are considered imbalanced - have roles in the involvement of children to become child soldiers and enter armed conflicts.

\section{Forms of Recruitment of Child Soldiers}

The presence of child soldiers in general is inescapable from the recruitment process itself. The process of recruiting children may occur in two ways ${ }^{17}$ :

a. Forced Recruitment

This kind of recruitment, which compels by force, may be conducted by the two parties to an armed conflict. This forced recruitment utilizes threats and even physical violence to the children to be recruited or to the people (families) closest to the children. Some states have even implemented a recruitment system with a forced method that has been

16 Enarda Cuni and Juelda Lamce, The Right to Protect Children under International Law: The Case of Child Soldiers', (2013) 2(8), Academic Journal of Interdisiplinary Studies, p.673. codified to the National Defense Law of the state.

b. Coercive or Abusive Recruitment (Recruitment with Psychological Intimidation and Violence)

This kind of recruitment involves situations where the recruitment process does not show proof of direct physical threats or intimidation toward the object of recruitment by the combative parties, but the evidence that exists indicates that the recruitment does not indicate the voluntary involvement of the children as child soldiers by one of the parties that recruit them. This kind of recruitment is commonly utilized by the combative parties, whether the local government or the separatist party, with the intent that the conducted recruitment would not be considered to cause intimidation or violence in any form to the children to be recruited.

International law rejects all forms of recruitment of child soldiers, whether the recruitment is voluntary, by force, or by coercion. The utilization of underage children as soldiers or troops on the battlefield may be classified as one of the forms of war crimes. The classification of the utilization of children as a form of war crime is stated in the 1998 Rome Statute of the International Criminal Court Article 8 Paragraph 2 Point b (xxvi), which states that: "Conscripting or enlisting children under the age of fifteen years into the national armed forces or using them to participate actively in hostilities"

In addition, the 1998 Rome Statute of the International Criminal Court also

17 Readings I: 'International Conflict Studies, Department of Peace and Conflict Research' (2002) Uppsala University, Sweden. p. 18-22 
contains a statement of regulations regarding the utilization of children in noninternational armed conflict, as found in Article 8 Paragraph 2 Point e (vii), which states: "Conscripting or enlisting children under the age of fifteen years into armed forces or groups or using them to participate actively in hostilities"

Article 8 Paragraph 2 Point e (vii) states that it is prohibited for children under the age of 15 years to be involved as well as to be recruited as members of armed troops by the combatant parties in a noninternational or internal conflict of a state. If in reality violations were committed of the article, the actions of the party considered to be violating party will be classified as a war crime.

Based on a report from the BBC news office, a case of child recruitment occurred with the forced recruitment method occurred in the Democratic Republic of Congo, when a 13 year-old child was forced by government armed troops to become one of their members. In front of the child, armed troops of the government shot down an older sibling of the child for rejecting the recruitment to become a member of armed troops of the government. The incident then left the child feeling frightened and led to the child becoming a member of the armed troops of the government at the age of only $13^{18}$. Another example of child soldier recruitment with the coercive or abusive recruitment method occurred in the territory of Afghanistan. Two generations in Afghanistan live in an environment with a culture of Kalashnikov (a kind of Russian-

18 DR Congo 'awash' with child soldiers http://news.bbc.co.uk, accessed March 27, 2020.

19 Sonja C. Grover, Child Soldier Victims of Genocidal Forcible Transfer: Exonerating Child Soldiers Charged with Grave Conflict-related International Crimes, (Springer, Heidelberg, 2012), p.1 made AK47 rifle). They live and develop amongst environments of schools and homes through a method that is very much connected to military equipment (tanks and weapons). Even several informal schools (madrasah) there became centers of indoctrination and recruitment of young warriors. The children of schooling age have already been taught methods of war, and yet they should learn about and receive beneficial knowledge in school; instead, they learn about knowledge they should not know at their age, as the knowledge of war. They use different kinds of weaponry, and they are immediately recruited as fighters to be put on the front line of warfare.

\section{Legal Protection toward Children Who Are Recruited as Child Soldiers Based on International Law}

The prohibition of the recruitment of children into armed military has fundamentally been regulated in international law, ${ }^{19}$ among others being regulated in international humanitarian law and international human rights law that essentially become the foundation of all international law. The prohibition against using children (under 15) in military operation or hostilities also fundamental protection for older children as well. ${ }^{20}$

Human rights are a kind of special demands that are strongly promoted by individuals or groups in society overall. ${ }^{21}$ Regulations that establish the limits of age of children who are not allowed to become participants in armed conflict are stated in Additional Protocol I of 1977, Convention on

20 Ibid, no 18, p.39

21 Chairul Bariah, Perlindungan Anak Menurut Konvensi Anak-Anak, Legal Protection According to the Child Convention, (USU Repository, Medan, 2006), p. 7. 
the Rights of the Child of 1989, and the Optional Protocol to the Convention on the Rights of the Child on the Involvement of Children in Armed Conflict of 2000.

The material of legal protection of the rights of children in the Convention on the Rights of the Child may be grouped into four categories of child rights ${ }^{22}$ :

a. Survival rights, as the rights found in Articles 6 and 24 of the Convention on the Rights of the Child, which are the rights of children in the convention that cover the rights to preserve and maintain life (the rights of life) and to attain the highest degree of health and healthcare (the right to the highest attainable standards of health and medicine).

b. Protection rights, which are the rights of children in the convention that cover the rights to protection from discrimination, violence, and abandonment for children who do not possess families, as children who are refugees and victims of armed conflicts.

c. Development rights), which are the rights of children in the convention that cover all forms of education (formal and non-formal) and the right to achieve a proper standard of living for the physical, mental, spiritual, moral, and social development of children.

d. Participation rights, which are the rights of children in the convention that cover the rights of children to be able to state their opinions for anything that affects them (the rights of a child to express her/his views in all matters affecting that child).

Article 4 Paragraph (3) of Additional Protocol II of the Geneva Convention on the
Protection of Victims of Non-International Armed Conflicts states that: "Children shall be provided with the care and aid they require, and in particular:

a) They shall receive an education, including religious and moral education, in keeping with the wishes of parents, or in the absence of their parents, of those responsible for their care;

b) All appropriate steps shall be taken to facilitate the reunion of families temporarily separated;

c) Children who have not attained the age of fifteen years shall neither be recruited in the armed forces or groups nor allowed to take part in hostilities;

d) The special protection provided by this Article to children who have not attained the age of fifteen years shall remain applicable to them if they take a direct part in hostilities despite the provisions of sub-paragraph (c) and are captured;

e) Measures shall be taken, if necessary, and whenever possible with the consent of their parents or persons who by law or custom are primarily responsible for their care, to remove children temporarily from the area in which hostilities are taking place to a safer area within the country and ensure that they are accompanied by persons responsible for their safety and wellbeing."

As well, Article 77 Paragraphs (2) and (3) of Additional Protocol I to the Geneva Convention of 1977 on the Protection of Victims in International Armed Conflict states that:

a) Article 77 Paragraph 2

22 UNICEF, Guide to the Convention on the Rights of the Child (CRC), UNICEF, Jakarta, p. 4. 
"The Parties to the conflict shall take all feasible measures in order that children who have not attained the age of fifteen years do not take a direct part in hostilities and, in particular, they shall refrain from recruiting them into their armed forces. In recruiting among those persons who have attained the age of fifteen years but who have not attained the age of eighteen years, the Parties to the conflict shall endeavour to give priority to those who are oldest."

b) Article 77 Paragraph 3

"If, in exceptional cases, despite the provisions of paragraph 2, children who have not attained the age of fifteen years take a direct part in hostilities and fall into the power of an adverse Party, they shall continue to benefit from the special protection accorded by this Article, whether or not they are prisoners of war."

From the two regulations above, it is stated that the age limit of children who cannot be recruited and utilized in armed conflict is 15 years of age. It also implies that armed group or state armed force have responsibility for not recruit children. ${ }^{23}$ This is different from the regulations in the Convention on the Rights of the Child of 1989, specifically in Articles 1, 2, and 3 of the Optional Protocol to the Convention on the Rights of the Child on the Involvement of Children in Armed Conflict of 2000, which state that people who have not reached the age of 18 years cannot participate directly in warfare.

Protection for children, as part of the group of people who are required to be protected, also apply to regions that are

23 Janet Mcknight, 'Child Soldiers in Africa: A Global Approch to Human Rights Protection, Enforcement and Post-Conflict Reintegration', occupied by the armed groups of one of the parties in the conflict, when an armed conflict. There are obligations that are regulated in The Fourth Geneva Convention for the ruling power during periods of occupation, specifically the obligation to protect children who are under 18 years of age to prevent their participation in armed forces by the rule of the currently ruling power. The protection for these rights of children are regulated in Article 51 of the Fourth Geneva Convention, which states that:

"The Occupying Power may not compel protected persons to serve in its armed or auxiliary forces. No pressure or propaganda which aims at securing voluntary enlistment is permitted."

"The Occupying Power may not compel protected persons to work unless they are over eighteen years of age, and then only on work which is necessary either for the needs of the army of occupation, or for the public utility services, or for the feeding, sheltering, clothing, transportation or health of the population of the occupied country."

In addition to the prohibition of utilization of civilians, particularly children who are under 18 years of age, for occupations that are considered improper as well as their recruitment into the armed forces of the currently ruling party in an area of occupation, The Fourth Geneva Convention also protects children who are under 18 years of age from the heaviest form of sanctions, as capital punishment. Article 68 of the Fourth Geneva Convention forbids

(2010) 18(2), African Journal of International and Comparative Law, p.117 
the imposition of capital punishment to someone who is under the age of 18 years if they are considered to violate the stipulations that are created by the rule of the currently ruling party. Article 68 states that:

"The death penalty may not be pronounced against a protected person unless the attention of the court has been particularly called to the fact that, since the accused is not a national of the Occupying Power, he is not bound to it by any duty of allegiance. In any case, the death penalty may not be pronounced against a protected person who was under eighteen years of age at the time of the offence."

Clearly, the Fourth Geneva Convention states that children are a part of civilians who are required to be protected and not be permitted to participate in armed conflict, and there needs to be respect for the human rights of children. Special treatment for children is intended to consider children naturally vulnerable to the risks they may face from armed conflict situations; this special protection also leads to the age limit for soldier recruitment into the armed forces of the ruling party in an occupied area as well as the renouncement of capital punishment for people under the age of 18 years.

The relationship between international humanitarian law and international human rights law, according to the integrity school of thought, is that international humanitarian law applies only for certain groups and in certain situations, while international human rights law applies for every person in every place at every time. This means that international humanitarian law applies

24 Muhammad Joni, above n 5, p. 29. during wartime conditions, while international human rights law applies in conditions of peace ${ }^{24}$.

Based on the stipulations above, it can be concluded that the age limit of children for non-recruitment as members of armed groups and non-participation in armed conflict is $\mathbf{1 5}$ years. This is based on the fact that international humanitarian law is the lex specialis of international human rights law during times of armed conflict, and thus the regulations that apply while armed conflicts occur are those of the Geneva Convention of 1949 with its Additional Protocol.

In addition to being regulated in the stipulations of the Additional Protocol to the Geneva Convention, legal protection of children who are recruited as child soldiers is also regulated in:

a. ILO (International Labour

Organization) Convention No. 182

Article 3 (a) ILO Convention No.

182:

"All forms of slavery or practices similar to slavery, such as the sale and trafficking of children, debt bondage and serfdom and forced or compulsory labour, including forced or compulsory recruitment of children for use in armed conflict;..."

Child soldiers in the convention of the ILO is formulated as one of the worst forms that child labor may take shape. ${ }^{25}$ This convention had been adopted by all members of the ILO and is binding for the party states that have signed and ratified it to take any immediate action in the best possible manner to issue prohibitions and eliminate all forms of the worst child labor. Then, the convention defines children as every person under the

25 Julie McBride, The War Crimes of Child Soldier Recruitment, (T.M.S Asser Press, The Hague, 2014), p.25 
age of 18 years and as a part of the definition of the worst forms of child labor.

b. Optional Protocol to the Convention on the Rights of the Child on the Involvement of Children in Armed Conflict

In 2000, the UN General Assembly announced that the members had adopted the Optional Protocol to the Convention on the Rights of the Child. This protocol comprises stipulations that must be executed and are required to be complied with by the parties that are in conflict when an armed conflict, different from the Convention on the Rights of the Child, which is required to be complied with even if armed conflict does not occur. This protocol raises the age standard for children who are utilized as child soldiers, which was previously established as 15 years, to 18 years. Articles 1 and 2 of this protocol state that:

a) Article 1

"States Parties shall take all feasible measures to ensure that members of their armed forces who have not attained the age of 18 years do not take a direct part in hostilities."

b) Article 2

"States Parties shall ensure that persons who have not attained the age of 18 years are not compulsorily recruited into their armed forces."

From the articles stated above, it is explained that state parties may conduct recruitment of children on a voluntary basis to join as a member of the national armed troops from an age of 16 years. States that conduct enlistment of children to become soldiers under the age of 18 years are required to consider patterns of safeguarding and protection, which includes permission given by parents or guardians of the children in question, and to be able to show proof of the actual age of the children. Then, the state of concern is obligated to inform everything about the lives of armed troops who live in army barracks, as well as to inform about their eventual rights and obligations if the children become willing to join armed troops. This protocol also establishes obligations for non-government armed groups. This is mentioned in Article 4, which states that: "Armed groups that are distinct from the armed forces of a State should not, under any circumstances, recruit or use in hostilities persons under the age of 18 years."

The Convention on the Rights of the Child and the Optional Protocol to the Convention of the Rights of the Child on the Involvement of Children in Armed Conflict do not regulate regarding underage children who have handled weapons, because based on reasoning, it can be understood that if there are no regulating laws, then the converse applies to what has happened in reality.

This also becomes the case for regulations that regard that underage children cannot become combatants, but in reality the situation occurs and there are no regulations - whether constitutional or international that regard them, and thus what applies is the converse, which is that the status of the underage children has become combatants.

\section{c. Rome Statute of the International Criminal Court}

The Rome Statute of the International Criminal Court was ratified and adopted by its state parties in July 1998. This statute defines the prohibition of the utilization of children under the age of 15 years to take part directly in armed conflicts, and the states or armed groups that commit the violation are classified to have committed war crimes. The courts can take individual action toward 
parties who have committed the act. However, all this can only apply for, and be conducted toward, states that have ratified the statute. In this statute, Article 7 Paragraph 1 Point (g) states that: "Rape, sexual slavery, enforced prostitution, forced pregnancy, enforced sterilization, or any other form of sexual violence of comparable gravity"

The article clearly states that international law through the Rome Statute of the International Criminal Court also forbids the utilization of children as sex slaves, and if this is violated, then the act will also be classified as a war crime and a crime against humanity.

One of the primary principles of international humanitarian law is the division of residents in a state territory that is experiencing war or is being involved in armed conflict into two categories, as combatants and civilians, and this principle is called the Distinction Principle. Therefore, the principle is intended to be able recognize the parties involved in armed conflict to find out who may become objects of violence and who are required to be protected because they are not involved in the conflict.

As civilians who do not take part in armed conflict, children obtain protection related to personal respect, family rights, wealth, and religious practice, as expressed in Article 27 of the Fourth Geneva Convention. Toward children, it is not permitted to commit acts that are forbidden in Articles 27 to 34 of the Fourth Geneva Convention, which comprise:

a. Committing physical and spiritual coercion to obtain details;

b. Committing acts that cause spiritual suffering;

c. Imposing collective punishments;

d. Committing intimidation, terrorism, and theft; e. Committing acts of retaliation (reprisal);

f. Making them hostages; and

g. Committing acts that may cause physical suffering or enmity toward protected people.

As people who are vulnerable toward attacks, children are entitled to special protection if an armed conflict occurs. Special protection toward children as regulated in international law, specifically in the Fourth Geneva Convention and the Additional Protocol to the Geneva Convention of 1977, cover:

a. Treatment of newborn babies, who are positioned as ill people;

b. Rights of children for care and aid;

c. Occupation of children under the age of 15 years in safe areas and zones, and hospitals;

d. The reunion of families who are separated by international or noninternational armed conflicts;

e. The temporary transfer of children on the grounds of their safety, particularly from siege and of those present in areas under siege;

f. Prohibition in cases of occupation by armed forces to compel protected people, particularly those under the age of 18 years, to work;

g. Protection of culture and education of children;

h. Prohibition to impose capital punishment to children under the age of 18 years if they commit violations;

i. Protection of rights of children who are accused, arrested, or exiled;

j. Protection of families, unchallenged by the status of children;

k. Prohibition to recruit children under the age of 15 years into armed forces; and 
1. Protection of orphans or children who are separated from their families.

Substantially, norms of international humanitarian law that regulates the protection toward children in armed conflict is found in the Geneva Convention relative to the Protection of Civilian Persons in Time of War and the Additional Protocol of the Geneva Convention of 1977. The legal protection afforded to children is more directed on the consequences of armed conflict that will afflict or affect them, as well as prohibitions and prevention that are required to be conducted by the parties of the conflict in relation to the recruitment of underage children to become combatants.

International human rights law, as the law regime that may be applied in any condition, specifically regulates the protection of children in armed conflict within the Convention on the Rights of the Child and the Optional Protocol on the Involvement of Children in Armed Conflict. However, in the region of Africa, where the utilization of underage children as combatants is well-known, the regulation of the protection of children in armed conflict is found within the African Charter on the Rights and Welfare of the Child of $1990^{26}$.

Within the Convention on the Rights of the Child of 1989, there are four principles of protection toward children:

a. Non-discriminative protection;

b. Best interests of the child;

c. The right to life, survival, and development for a child; and

d. Respect for the views of the child.

The four primary matters of the Convention on the Rights of the Child is affirmed to ensure the occurrence of respect and protection toward children rights by states and the global community. As an international treaty, the Convention on the Rights of the Child is ratified by almost all states in the world, but the ratification is not the final goal of the convention. Its execution in law, policies, habits, and everyday practices is the ultimate goal of the intent to create the Convention on the Rights of the Child $^{27}$.

Law enforcement of violations toward humanitarian law becomes something that is very important to prevent repeated violations. As well, for violations committed by war participants toward the rights of children, firm sanctions must be imposed. The 31 rights of children in the Convention on the Rights of the Child in relation to wartime conditions cover:

a. The right to obtain special protection during an armed conflict;

b. The right to obtain special protection in times of conflict;

c. The right to obtain special protection in emergency situations;

d. The right to obtain special protection as refugees;

e. The right to obtain personal protection;

f. The right to obtain protection from torture;

g. The right to obtain protection from abuse and inhumane punishments and treatments; and

h. The right to obtain protection from arbitrary arrest or detention.

Protection needs to be given by considering the nature of children who are vulnerable and need to be protected, and as such, it becomes necessary to improve the quality of protection toward children form their involvement in armed conflict. 
Therefore, an age limit for the recruitment of troops to become members of armed groups was established, which was 15 years based on Article 38 of the Convention on the Rights of the Child. However, the age limit was then increased to 18 years through the Optional Protocol to the Convention on the Rights of the Child on the Involvement of Children in Armed Conflict. This was performed with the consideration that children who are 18 years old possess greater capacity for logical thinking and thus are able to differentiate good from bad, as well as to determine their own futures.

The General Assembly of the UN in 2000 adopted the Convention on the Rights of the Child. Through special stipulations for the protection of children in situations of armed conflict, the Convention on the Rights of the Child states, through Article 38:

1. "States Parties undertake to respect and to ensure respect for rules of international humanitarian law applicable to them in armed conflicts which are relevant to the child."

2. "States Parties shall take all feasible measures to ensure that persons who have not attained the age of fifteen years do not take a direct part in hostilities."

3. "States Parties shall refrain from recruiting any person who has not attained the age of fifteen years into their armed forces. In recruiting among those

28 Article 38 of the Convention on the Rights of the Child:

(1) States parties are required to have and ensure respect of international humanitarian law in an occurring armed conflict, particularly regarding children;

(2) States parties are required to take necessary action to make sure that people who are not yet 15 years old are not directly involved in combat;

(3) States parties are required to prevent recruitment of people who are not yet 15 years old for the aim of armed conflict. If in a recruitment there are people who are 15 years persons who have attained the age of fifteen years but who have not attained the age of eighteen years, States Parties shall endeavour to give priority to those who are oldest."

4. "In accordance with their obligations under international humanitarian law to protect the civilian population in armed conflicts, States Parties shall take all feasible measures to ensure protection and care of children who are affected by an armed conflict." 28

Article 38 of the Convention on the Rights of the Child affirms that all states party to the convention are required to ensure and respect the rights of children, in particular children who live in an environment currently experiencing armed conflict. States parties are also obligated to be able to protect the interests of existing children, and to be able to establish age limits in the recruitment of children as candidate soldiers for armed groups, whether for those of the government that are considered legal or those of the opposition, which are usually insurgent armed groups whose presence are considered illegal. Moreover, it also stated that state is prohibited to recruit child under fifteen as soldier or combatant29.

As with the Optional Protocol to the Convention on the Rights of the Child on the Involvement of Children in Armed Conflict,

old but there are also people older than 15 years, states parties are required to prioritize older people;

(4) Based on stipulations of international humanitarian law for protection of civilians when an armed conflict occurs, states parties are required to take action to make sure that children who become victims of an armed conflict are protected and cared for.

29 J A Robinson, 'The Right of Child Victims of Armed Conflict to Reintegration and Recovery', (2012) 15, Potchefstroom Electronic Law Journal, p.54 
the African Charter on the Rights and Welfare of the Child 1990 that becomes the guideline for the protection of children rights in Africa also regulate the protection of children in armed conflicts. Article 22 of the African Charter affirms the following:

a. States parties are required to take all effective measures to ensure that there will not be any children who take part or become involved directly in the struggle of conflicting parties.

b. States parties are required to hold back, particularly in terms of child recruitment. Article 2 of this Charter defines that children are every person under the age of 18 years.

c. In accordance with the obligations based on international humanitarian law to protect civilians in situations of armed conflict, states parties are required to take all measures that can ensure protection and care for children who are affected by armed conflict that occurs in the environment where they live. Protection and care in this case also includes the recovery of children who become physical or psychological victims.

Next, for the parties that peruse child soldiers, a state may be imposed sanctions. One of the forms of the sanctions may be compensatory payment based on Article 91 of Additional Protocol I of 1977, rule 149 of customary international humanitarian law, and collective responsibility. In addition to the state, commanders who make use of child soldiers cannot be removed from

30 Haryomataram, Pengantar Hukum Humaniter [Introduction to Humanitarian Law], (PT. Raja Grafindo Persada, Jakarta, 2007), p. 75.

31 Michael E. Kurth, 'The Lubanga Case of International Criminal Court: A critical Analysis of the Trial Chamber's Findings on Isuues of Active Use, Age, and Gravity', (2013) Goetingen Journal of International Law, P. 433 responsibility based on commander responsibility as regulated in Article 28 of the Rome Statute ${ }^{30}$.

Moreover under the Lubanga Case, child under fifteen years old could not be enlist as a soldier. ${ }^{31}$ The prohibition against using children under the age of 15 to participate actively in hostilities is not dependent on the individuals concerned having been earlier conscripted or enlisted into the relevant armed force or group. ${ }^{32}$ The trial chamber conclude that child under fifteen could not and unable to give consent to be part of armed group. Consequently, even if the child voluntary joins the armed force, it still wrong to accept them to be part of the armed force. Also in the Ntaganda case, "conscripting and enlisting child under 15 years old to use them as soldier who taking actively in hostilities is undoubtedly very serious crimes" $" 33$. The ICC also stated that "the impact to child soldier under 15 is significant" 34 .

\section{CONCLUSION AND SUGGESTION}

Many factors cause the recruitment of children as child soldiers in times of conflict, but what is the most dominant is that children are involved because of the interests of adults (those who are in conflict), not on the basis of the interests or desires of the children. Active involvement of children in armed conflict is not justified by any form of law. Children have the right to safe and comfortable living for their proper development. The various international legal instruments that regulate regarding the

32 Prosecutor v. Thomas Lubanga Dylo, ICC Trial Chamber I, No.: ICC-01/04-01/06, 14 March 2012, para 604-605

33 The Prosecutor v. Bosco Ntaganda, ICC Trial Chamber IV, Sentencing Judgment, No: ICC01/04-02/06, 7 November 2019, para. 179

34 ibid., para 184 
prevention, protection, and even enforcement for violators of different international legal instruments regarding the recruitment of children as child soldiers have actually not been able to decrease the number of children who become victims in armed conflict and are particularly directly involved as child soldiers. The reason for this is that normatively, there are still some problems related to the uniformity of definition for the age of children, as well as the classic problem of the binding power of all international legal instruments related to the issue, regarding whether they do or do not give rise to compulsory obligation. However, child under age of 15 absolutely could not be recruit as child soldier involuntary or voluntary.

It needs to be understood that children possess fundamental rights that must be fulfilled by the state as a duty barrier for the human rights of children, both during times of peace and armed conflicts. Therefore, legal protection for children who are recruited as child soldiers in times of armed conflict, seen from the perspective of human rights, becomes obligatory. This is in reference to the principles of human rights that have become basic norms (ius cogens) to which all states must comply. If a state does not grant protection to children and even allows them to be directly involved in armed conflict, international legal sanctions may then be imposed.

\section{ACKNOWLEDGEMENT}

We would like to thank all members of the international law department of the Faculty of Law, Universitas Brawijaya for all support in the research process and the preparation of this paper.

\section{REFERENCE}

\section{Books}

Bariah, Chairul, Perlindungan Anak Menurut

Konvensi Anak-Anak, Legal

Protection According to the Child

Convention, (USU Repository,

Medan, 2006)

Haryomataram, Pengantar Hukum

Humaniter [Introduction to

Humanitarian Law], (PT. Raja

Grafindo Persada, Jakarta, 2007)

Joni, Muhammad, Aspek Hukum

Perlindungan Anak Dalam Perspektif

Konvensi Hak Anak [Aspects of Child

Protection Law in the Perspective of the Convention on the Rights of the Child], (P.T Citra Aditya Bakti, Bandung, 1999) McBride, Julie, The War Crimes of Child Soldier Recruitment, (T.M.S Asser Press, The Hague, 2014).

Melzer, Nils, International Humanitarian

Law: A Comprehensive Introduction,

(ICRC, Geneva, 2019)

Grover, Sonja C. , Child Soldier Victims of

Genocidal Forcible Transfer:

Exonerating Child Soldiers Charged with Grave Conflict-related International Crimes, (Springer, Heidelberg, 2012)

UNICEF, Guide to the Convention on the Rights of the Child (CRC), UNICEF, Jakarta.

\section{Journals and Reports}

Cuni, Enarda and Juelda Lamce, 'The Right to Protect Children under International Law: The Case of Child Soldiers', (2013) 2(8), Academic Journal of Interdisiplinary Studies.

Drumbl, Mark A.,The 'Effects of The Lubanga Case on Understanding and Preventing Child Soldering' (2012) 1 Yearbook of International Humanitarian Law. 
Graham, George, and Kirollos, Mariam, (Report writer), 'Stop The War on Children', (2019), VierCprint+mediafabrik, Germany

Haer, Roos, 'The Study of Child Soldering: Issues and Consequences for DDR Implementation' (2016) Third World Quartely

Mcknight, Janet, 'Child Soldiers in Africa: A Global Approch to Human Rights Protection, Enforcement and PostConflict Reintegration', (2010) 18(2), African Journal of International and Comparative Law.

Kurth, Michael E., 'The Lubanga Case of International Criminal Court: A critical Analysis of the Trial Chamber's Findings on Isuues of Active Use, Age, and Gravity', (2013) Goetingen Journal of International Law

Robinson, J A , 'The Right of Child Victims of Armed Conflict to Reintegration and Recovery', (2012) 15, Potchefstroom Electronic Law Journal.

Rashid, Sulaf Abdullah Hama, 'International Protection for Victim of Sexual Violance During Armed Conflict', (2020) 7 Jurnal of Critical Review.

Mungoven, Rory. 'Global Report on Child

Soldiers Part 1'.,(2018), Child Soldiers Global Report

Readings I: 'International Conflict Studies, Department of Peace and Conflict Research' (2002) Uppsala University, Sweden

Ve savasin, Çocuklar and Etkileri, Saglik, 'Children and Health effects of War: Being A War Child', (2017) 39 (4) Cumhuriyet Medical Journal.
Additional Protocol I of Geneva Convention 1977

Convention on the Rights of the Child 1989

Geneva Convention 1949

ILO Convention

Optional Protocol to The Convention on The Rights of the Child on the involvement of Children in Armed Conflict entry into force 2002.

Rome Statute

Lubanga Dylo, ICC Trial Chamber I, Judgement Pursuant to Article 74 of the Statute, No.: ICC-01/04-01/06, 14 March 2012, para 604-605

The Prosecutor v. Bosco Ntaganda, ICC Trial Chamber IV, Sentencing Judgment, No: ICC-01/04-02/06, 7 November 2019, para. 179

\section{Internet}

Benekdita Miranti, UNICEF: 2010-2019 Jadi Dekade Mematikan Bagi Anak Daerah Konflik [UNICEF: 20102019 Becomes the Most Deadly Decade for Children in Areas of Conflict], https://www.liputan6.com/ global/read/4145033/unicef-20102019-jadi-dekade-mematikan-bagianak-daerah-konflik, accessed on April 10, 2020.

BBC News Indonesia, Serangan terhadap anak di wilayah perang sangat mengejutkan [Attacks on children in war areas are very surprising], https://www.bbc.com/indonesia/maja lah-42501881, accessed on April 10, 2020.

Why children join, http://www.childsoldiers.org/childsoldiers/whychildren-join, accessed March 20, 2020.

DR Congo 'awash' with child soldiers http://news.bbc.co.uk, accessed March 27, 2020.

\section{Regulations}

